\title{
STUDI POLA PEMANFAATAN RUANG TERBUKA PUBLIK DI UNIVERSITAS NEGERI JAKARTA (KAMPUS A) BERDASARKAN KEMAMPUAN PETA MENTAL MAHASISWA PENDIDIKAN GEOGRAFI TAHUN ANGKATAN 2016
}

\author{
${ }^{1}$ Wulan Azahra Khairunisa, ${ }^{2}$ Ditha Khoirul Ummah, ${ }^{3}$ Agustiani Putri \\ 1,2 Program Studi Pendidikan Geografi Universitas Negeri Jakarta \\ ${ }^{3}$ Program Studi Pendidikan Matematika Universitas Negeri Jakarta
}

Email: wulanazahra49@gmail.com

\begin{abstract}
ABSTRAK
Penelitian ini bertujuan untuk mengetahui pola pemanfaatan ruang terbuka publik berdasarkan peta mental mahasiswa Program Studi Pendidikan Geografi, Universitas Negeri Jakarta. Peta mental adalah peta yang diambil dari pikiran manusia (cognitive map) mengenai lingkungan yang dilihatnya. Permasalahan kerap terjadi ketika menggambarkan peta mental yang disebut sebagai distorsi atau pergeseran dari keadaan sebenarnya baik secara fisik maupun makna dari lingkungan sendiri. Upaya pemahaman mengenai Ruang Terbuka Publik (Public Open Space) berdasarkan peta mental di wilayah kampus A Universitas Negeri Jakarta dilakukan untuk megetahui interaksi manusia dengan lingkungan fisik dan sosialnya. Pada ruang lingkup kampus, ruang terbuka publik merupakan ruang tempat bertemunya interaksi berupa aktivitas-aktivitas oleh mahasiswa. Metode yang digunakan dalam analisis data penelitian adalah kualitatif deskriptif dan kualitatif rasionalistik. Angket (kuisioner) yang digunakan dalam penelitian ini menggunakan pertanyaan terbuka menggunakan tipologi stimulus grafis (gambar denah UNJ) dan nonverbal (pertanyaan seputar peta tersebut). Hasil yang diperoleh berdasarkan hasil kuesioner dari 69 responden mahasiswa Program Studi Pendidikan Geografi tahun angkatan 2016, sebagai berikut: Teater Terbuka, Tugu/Plaza UNJ, dan lapangan rumput dibelakang Tugu/Plaza UNJ yang umum disebut sebagai Taman/Bukit Teletubbies merupakan Ruang-ruang Terbuka Publik yang paling banyak diketahui dengan persentase $74 \%, 72 \%$, dan 55\%. Sedangkan, intensitas pemanfaatan tidak selalu berbanding lurus dengan banyaknya responden yang mengetahui Ruang Terbuka Publik (RTP) tersebut. Teater Terbuka hanya memiliki intensitas pemanfaatan sebesar $8,7 \%$. Pola pemanfaatan Ruang Terbuka Publik berdasarkan mahasiswa pendidikan geografi tahun angkatan 2016 berorientasi pada pusat kampus dan Fakultas Ilmu Sosial yang merupakan pusat kegiatan mahasiswa tersebut.

Kata Kunci: Aktivitas, Lingkungan, Mahasiswa, Peta Mental, Ruang Terbuka Publik
\end{abstract}

\section{ABSTRACT}

This study aims to determine the pattern of public open space use based on mental maps of Geography Education Study Program students, Jakarta State University. Mental maps are maps taken from the human mind (cognitive map) 
about the environment they see. Problems often occur when describing mental maps which are referred to as distortions or shifts from actual conditions both physically and meaningfully from the environment itself. The effort to understand the Public Open Space based on mental maps in the campus area of Jakarta State University was conducted to find out human interaction with the physical and social environment. In the scope of the campus, public open space is a space where the interaction between activities by students meets. The method used in the analysis of research data is descriptive qualitative and qualitative rationalistic. Questionnaires (questionnaires) used in this study use open questions using graphical stimulus typologies (UNJ floor drawings) and nonverbal (questions about the map). The results obtained based on the results of questionnaires from 69 respondents of the 2016 Geography Education Study Program, are as follows: Open Theater, Tugu / Plaza UNJ, and grass field behind Tugu / Plaza UNJ commonly referred to as Taman / Bukit Teletubbies are Open Spaces The most widely known public with a percentage of $74 \%$, $72 \%$, and $55 \%$. Meanwhile, the intensity of utilization is not always directly proportional to the number of respondents who know the Public Open Space (RTP). The Open Theater only has an utilization intensity of $8.7 \%$. The pattern of utilization of Public Open Space is based on the 2016 geography education students oriented to the center of the campus and the Faculty of Social Sciences which is the center of student activities.

Keywords: Activities, Environment, Students, Mental Maps, Public Open Space

\section{PENDAHULUAN}

Hubungan manusia dengan lingkungannya dapat terekam melalui peta mental. Peta mental ialah kemampuan manusia ketika mampu menggambarkan peta mengenai lingkungan sekitar tanpa pernah melihat peta asli pada wilayah tersebut. Keakraban dengan lingkungan merupakan salah satu komponen yang mempengaruhi peta mental individu. Menurut Peter Gould dan Roudney White dalam bukunya Mental Maps (1986), menjelaskan bahwa konsep mengenai lingkungan merupakan elemen terpenting dari gambar mental. Hubungan manusia dengan lingkungannya bersifat saling menyesuaikan dengan kemampuan kognisi yang dimilikinya oleh karena itu manusia akan selalu berusaha untuk memperoleh keselarasan dengan lingkungannya.

Permasalahan kerap terjadi ketika menggambarkan peta mental yang disebut sebagai distorsi atau pergeseran dari keadaan sebenarnya baik secara fisik maupun makna dari lingkungan sendiri. Distorsi fisik, sebagai contoh penelitian yang dilakukan oleh Fatemeh Imani dan Marzieh Tabaeian (2011) hasilnya menunjukkan bahwa sebagian besar menghilangkan jalan-jalan kecil hingga bangunan-bangunan pemerintahan yang menjadi kunci lokasi tersebut tidak digambar di dalam peta. Sedangkan, distorsi makna, sebagai contoh, penelitian yang dilakukan oleh Agus Dharma Tohjiwa (2011) mengenai citra pusat kota Depok berdasarkan peta kognitif masyarakat Depok sebagai pengamat, 
Berikut ini adalah beberapa tahapan yang dilakukan dalam pengumpulan data yaitu sebagai berikut:

1.Tipologi presentasi stimulus grafis

Pengamat diminta untuk membuat sketsa-sketsa peta Universitas Negeri Jakarta dengan sedikit mengendalikan interpretasi pengamat mengenai jarak dan bentuk.

2.Tipologi presentasi stimulus nonverbal

Pengamat diberikan sejumlah pertanyaan setelah tahap tipologi presentasi stimulus grafis dilaksanakan. Pada tahap ini, pertanyaan diajukan secara tertulis dengan cara eksplorasi berkaitan dengan hasil pembuatan sketsa peta. Tujuan presentasi stimulus nonverbal adalah untuk mendapatkan informasi dan pengamat berkaitan dengan "makna" objek penelitian.

Tipologi presentasi stimulus nonverbal dilakukan dalam dua bagian. Bagian pertama, pengamat diminta untuk menjawab pertanyaan tentang elemen-elemen fisik manakah yang sudah digambar yang paling mudah untuk dipahami dan paling memberikan kesan. Bagian kedua, pengamat diminta untuk menunjukkan (dengan sketsa) pada bagian-bagian manakah dalam sketsa peta yang sudah digambar sebagai tempat yang paling mudah untuk berorientasi beserta elemen-elemen fisik yang menyertainya dalam hal ini elemen fisik yang dimaksud adalah ruang terbuka publik.
Teknik analisis data menggunakan statistik deskriptif. Analisis data dilakukan dengan cara mengitung frekuensi ruang terbuka publik serta pemanfaatan yang disebutkan responden. Persentase tersebut digunakan untuk menentukan intensitas pemanfaatan ruang terbuka publik. Selain itu, persentase juga digunakan saat menghitung elemen-elemen pada peta mental untuk menentukan kelengkapan informasi pada peta mental responden.

Adapun populasi dan dalam penelitian ini adalah mahasiswa Program Studi Pendidikan Geografi Universitas Negeri Jakarta tahun angkatan 2016. Jumlah populasi yang diteliti adalah 69 mahasiswa yang merupakan $3 / 4$ bagian dari keseluruhan populasi.

\section{HASIL DAN PEMBAHASAN}

1.Ruang Terbuka Publik yang Disebutkan Responden

Berdasarkan akumulasi jawaban responden, terdapat 29 Ruang Terbuka Publik (RTP) yang diketahui. Hasil yang diperoleh pada kuesioner bagian A kolom "Ruang Terbuka Publik di UNJ" menurut pemahaman responden pada kuesioner bagian A sebagai berikut; mayoritas Ruang Terbuka Publik (RTP) yang diketahui responden ialah Teater Terbuka (Terbuk) yakni sebanyak 51 orang dengan persentase $74 \%, 50$ orang yang menyebutkan Tugu/Plaza UNJ dengan persentase $72 \%$, dan 
$55 \%$ responden menyebutkan lapangan rumput dibelakang Tugu/Plaza UNJ yang umum disebut sebagai Taman/Bukit Teletubbies yakni sebanyak 38 orang.

Persentase sedang berdasarkan Ruang Terbuka Publik (RTP) yang disebutkan ialah Arena Prestasi FIS sebanyak 33 orang dengan persentase $48 \%$, Kantin Blok M yang disebutkan sebanyak 19 orang dengan persentase 27,50\%, dan pendopo depan BAAK sebanyak 15 orang dengan persentase sebesar 21,70\%.

Persentase terendah berdasarkan Ruang Terbuka Publik (RTP) yang disebutkan oleh responden dalam jumlah minoritas yaitu pendopo seni musik, perpustakaan FIS, Taman Gd. Ki Hajar Dewantara, Lab FT, dan Gedung Dewi Sartika (GDS) lantai dua yang masingmasingnya memiliki bobot persentase sebesar $1,4 \%$.

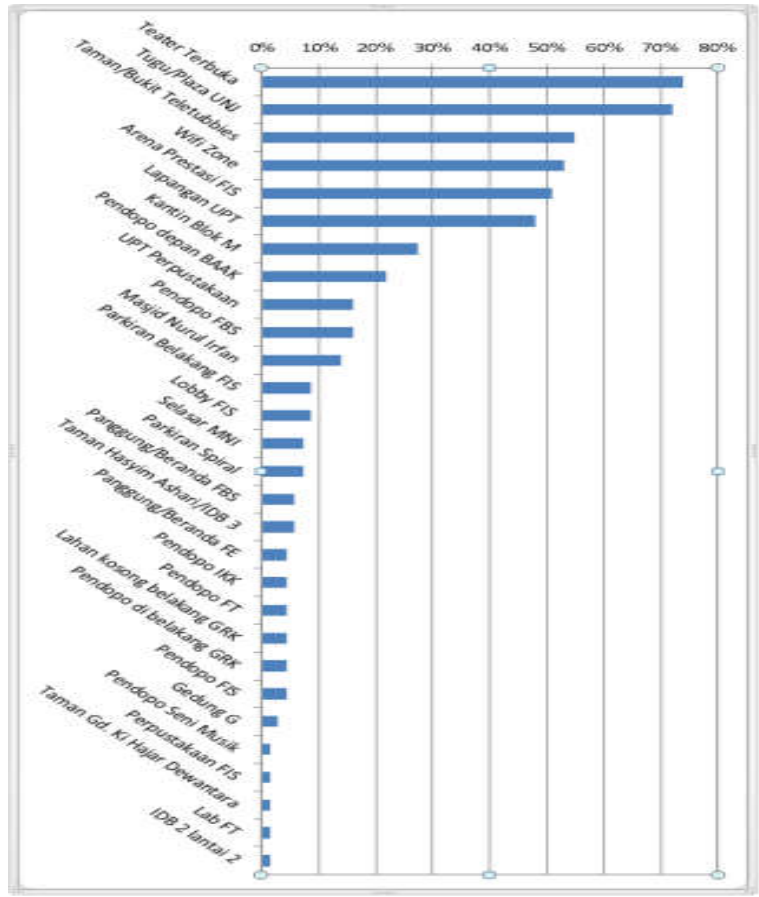

Gambar 1. Persentase Ruang Terbuka Publik yang Diketahui, dari Total 69 Responden

2. Kategori Fisik Ruang Terbuka Publik yang Disebutkan

Hasil yang diperoleh pada kolom "Lokasi dan Deskripsi Fisik" ialah lokasi yang disebut oleh responden menjelaskan asosiasi Ruang Terbuka Publik (RTP) tersebut dengan objek lain disekitarnya. Semakin banyak frekuensi responden yang menyebutkan RTP tersebut maka penjelasan mengenai lokasi tersebut semakin kaya begitu pun sebaliknya. Sedangkan, pada deskripsi fisik, responden menjawab berdasarkan tampilan fisik yang dilihat meliputi kategori fisik indoor/outdoor (misal; lapangan terbuka, bangunan bertingkat), bentuk (misal; persegi panjang, spiral, dan lain-lain), warna, dan keberadaan objek di dalam RTP tersebut (misal; rumput dan ring basket (lapangan), buku-buku 
(perpustakaan), bangku dan atap (pendopo) dan lain-lain.

\section{Pemanfaatan Ruang Terbuka Publik} Hasil yang diperoleh pada kuesioner kolom "Aktifitas yang Dilakukan" bervariasi. Berdasarkan objek yang memanfaatkannya pada umumnya Ruang Terbuka Publik (RTP) dimanfaatkan untuk aktifitas yang melibatkan orang banyak. Meskipun, juga terdapat RTP yang baik untuk individu. Sedangkan, berdasarkan tujuan pemanfaatannya dapat dibedakan RTP untuk tujuan

Kemudian, RTP berdasarkan fungsionalnya dapat dibedakan menjadi RTP yang diperuntukkan (formal) dengan RTP yang fungsionalnya tergantung dari adanya aktifitas mahasiswa yang memanfaatkannya (non formal).

\section{Pola Pemanfaatan Ruang Terbuka Publik}

Intensitas pemanfaatan tidak selalu berbanding lurus dengan banyaknya responden yang menyebutkan RTP tersebut. Meskipun, Teater Terbuka menduduki peringkat pertama untuk kategori Ruang Terbuka Publik (RTP) yang disebutkan oleh responden yakni sebanyak 74\% namun intenstas pemanfaatannya hanya $8,7 \%$ yang sering memanfaatkan.

RTP lain yang juga berbanding terbalik meskipun disebutkan oleh banyak responden yakni Arena Prestasi Fakultas Ilmu Sosial (FIS), dan Lapangan UPT. Arena Prestasi (Apres) FIS dikenali oleh responden dengan persentase sebanyak 51\% akan tetapi intensitas pemanfaatan sering hanya mencapai $14.6 \%$. akademik (misal; mengerjakan tugas), organisasi, dan kepentingan pribadi. Berdasarkan kategori fisik, RTP indoor dan outdoor mempengaruhi aktivitas yang dilakukan.

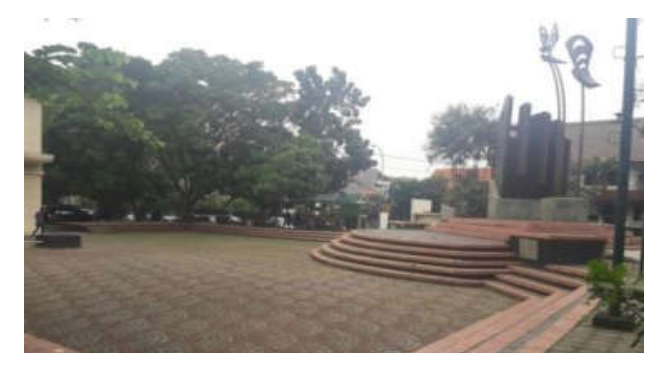

Gambar 2. Teater Terbuka sebagai Ruang Terbuka Publik yang Paling Banyak Disebutkan oleh Responden

Lapangan UPT yang disebutkan oleh responden dengan persentase $48 \%$ namun pemanfaatannya hanya 17,45 persen.

Pada bagian pertama kuesioner peneliti menemukan kecenderungan terdapat Ruang Terbuka Publik (RTP) yang sering maupun jarang dikunjungi memiliki hubungan dengan kondisi visual dan fungsional RTP tersebut. RTP yang sering dikunjungi bermakna fungsionalnya serta kondisi visual yang baik, diantaranya Taman (Bukit) Teletubbies.

Namun, ada pula RTP yang sering dikunjungi bermakna fungsionalnya berjalan baik meskipun kondisi fisiknya kurang baik seperti Kantin Blok $\mathrm{M}$ dan Wifi Zone. Hal ini didasarkan pada fungsi ruang publik itu sendiri, karena terjadi karena adanya interaksi Ruang Terbuka Publik (RTP) dengan individu di dalamnya. . Kategori untuk RTP dapat dikategorikan sebagai Ruang Terbuka Publik indoor dan outdoor 
yang merupakan outdoor waktu kunjungan merupakan sore hari

Pola pemanfaatan Ruang Terbuka Publik (RTP) menggambarkan kecenderungan korelasi RTP tersebut dengan jarak. Aktifitas mahasiswa pendidikan geografi angkatan 2016 mempengaruhi RTP yang disebutkan dimana penyebarannya dekat ataupun didalam dengan FIS sebagai tempat kuliah utama, serta IDB I (Gedung R.A Kartini) dan IDB II (Gedung Dewi Sartika).

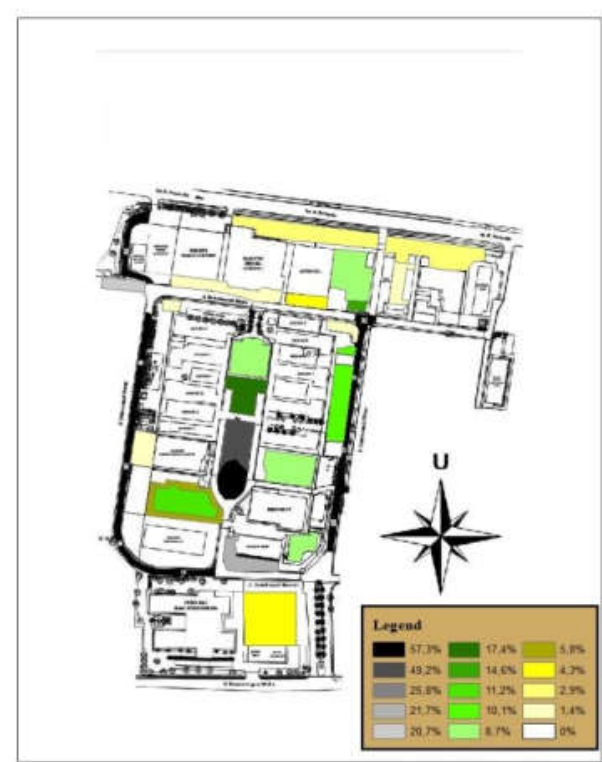

Gambar 3. Denah Intensitas Pemanfaatan Ruang Terbuka Publik Di Universitas Negeri Jakarta
5. Masalah yang Muncul ketika Menggambar Denah UNJ Berdasarkan Peta Mental

Responden yang kesulitan menggambar denah UNJ ketika ditelusuri lebih lanjut melalui wawancara menyatakan bahwa gaya hidup responden hanya bergantung pada aktifitas formal (kuliah).

"Aktifitas selain datang kuliah di kelas tergantung sih biasanya pulang, tapi kadang rapat kalau ada rapat, atau main.Kalau dilihat dari intensitasnya lebih banyak langsung pulang".

Setelah selesai kuliah responden terbiasa untuk langsung pulang sehingga responden tidak banyak menghabiskan waktunya di kampus.

"Ikut organisasi tapi tapi kurang aktif, organisasinya itu Pusat Studi Mahasiswa (PUSDIMA)". (A.H)

Ketika ditanyakan lebih jauh ternyata responden tersebut sebenarnya mengikuti satu organisasi dalam ruang lingkup fakultas. Akan tetapi, organisasi tersebut tidak cukup aktif mengadakan kegiatan. Sehingga, responden jarang memiliki kegiatan lain selepas kuliah

6. Kemudahan dalam Menggambar Denah UNJ Berdasarkan Peta Mental

Sebaliknya, gaya hidup seorang organisatoris memiliki kemampuan peta mental paling lengkap. Hal tersebut disesbabkan waktu yang dihabiskan untuk berada di kampus lebih banyak dibandingkan orangorang yang tidak memiliki atau bergabung dalam organisasi. 
Sehingga, memiliki waktu yang cukup untuk mengenal lingkungan kampus untuk membangun mental imagery mengenai denah kampus.

"Selalu muter- muter UNJ untuk mengurusi surat- surat kegiatan atau bertemu dengan anggota satu organisasi beda fakultas. Untuk sabtu minggu juga tapi hanya jika ada acara kegiatan dari organisasi. Waktunya biasanya di UNJ dari jam 6 pagi sampai jam 10 malam."

Khususnya, responden tersebut mengikuti organisasi lebih dari satu, melalui kegiatan organisasi maka mobilitas yang dilakukan di lingkungan kampus yakni mengunjungi ruang-ruang terbuka publik lebih beragam.

"Aktifitas di UNJ yang pertama itu pagi biasanya menginap di gedung $G$ mandi di Gedung $G$, jika ada kuliah biasanya langsung ke kelas, tapi jika tidak ada kelas biasanya ke sekret ICA atau sekret BEMP, atau sekret KOPMA, dan atau sekret BEM FIS pokoknya di anatara empat itu ada kegiatan,...'(R.D.P)

7. Kualitas Ruang Terbuka Publik Berdasarkan Pengamatan Visual Responden

\begin{tabular}{|c|c|c|}
\hline No. & Ruang Terbuka Publik & Alasan \\
\hline 1. & \begin{tabular}{|l|} 
Tugu (Plaza) UNJ \\
\end{tabular} & $\begin{array}{l}\text { - Merupakan ikon dari UNJ } \\
\text { sehingga kondisinya baik } \\
\text { - Terurus, bersih, dan } \\
\text { pemanfaatannya maksimal } \\
\text { - Karena aset paling penting } \\
\text { di UNJ }\end{array}$ \\
\hline 2. & IDB (I, II, dan III) & $\begin{array}{l}\text { - Karena kondisinya bersih } \\
\text { dannyaman di dalamnya } \\
\text { - gedung baru, megah dan } \\
\text { fasilitasnya terpenuhi } \\
\text { - Perawatannya rutin }\end{array}$ \\
\hline 3. & Lapangan UPT & $\begin{array}{l}\text { - Karena palingmendominasi } \\
\text { gambar peta }\end{array}$ \\
\hline 4. & Teater Terbuka (Terbuk) UNJ & $\begin{array}{l}\text { - Bersih dan nyaman untuk } \\
\text { tempat berkumpul dan } \\
\text { bersantai }\end{array}$ \\
\hline 5. & Wifi Zone & Karena terawat \\
\hline 6. & \begin{tabular}{|l} 
Taman Hasyim Ashari \\
\end{tabular} & $\begin{array}{l}\text { Karena persis di gedung IDB III } \\
\text { jadi pusat perhatian }\end{array}$ \\
\hline 7. & \begin{tabular}{|l|} 
Teletubbies \\
\end{tabular} & \begin{tabular}{|l|} 
Strategis dan sering dikunjungi \\
\end{tabular} \\
\hline
\end{tabular}

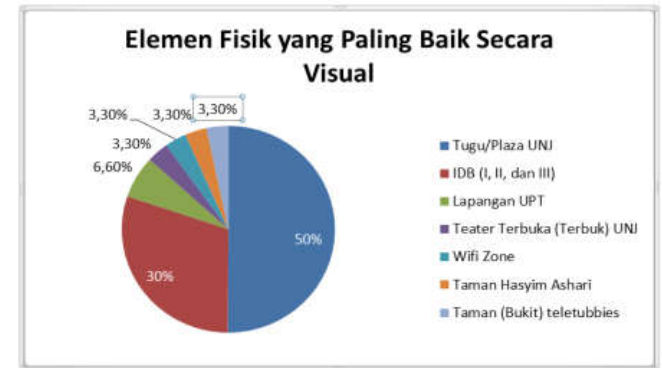

Gambar 6. Diagram Pie Elemen Fisik yang Paling Baik Secara Visual

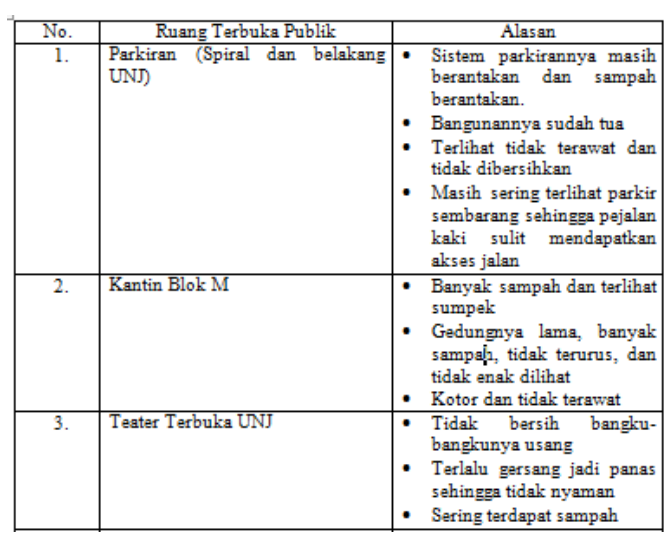

Elemen Fisik yang Paling Buruk secara Visual
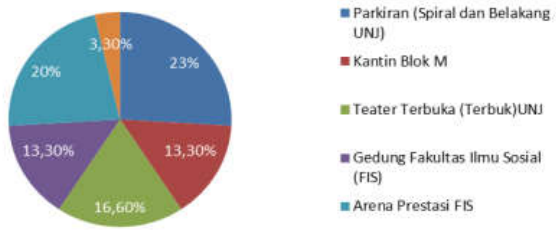

Gambar 7. Diagram Pie Elemen Fisik yang Paling Buruk Secara Visual

\section{KESIMPULAN}

Pola pemanfaatan sangat berkaitan dengan lokasi, RTP yang paling banyak disebutkan oleh responden sebanyak 74\% yakni Teater Terbuka (Terbuk) 
UNJ, letaknya sangat strategis di dekat pintu utama UNJ, memiliki kaitan dengan mental imagery responden sebab pada saat pertama kali datang ke UNJ letaknya dekat dengan BAAK yang merupakan tempat untuk mengurus berkas-berkas daftar ulang. Selain itu, adanya landmark berupa sculpture yang disebut responden sebagai patung "kupukupu" juga menambah daya visual responden.

Pola pemanfaatan Ruang Terbuka Publik (RTP) mengikuti

\section{DAFTAR PUSTAKA}

Gould, Peter. White, Rodney. 1986. Mental Maps. London: Berne Convention.

Haryanti, Dini. 2008. Kajian Pola Pemanfaatan Ruang Terbuka Publik Kawasan Bundaran Simpang Lima Semarang. Tesis: UNDIP.

Imani, Fatemeh. Tabaeian, Marzieh. 2011. Recreating Mental Image With The Aid Of Cognitive Maps And Its Role In Environmental Perception.

Procedia - Social and Behavioral Sciences 32 (2012) $53-62$.

Killworth, Peter. Bernard, H. 1982. A Technique for Comparing Mental Maps. Nedherlands: Social Networks 3 (1982) 307312. orientasi aktifitas utama mahasiswa yang memanfaatkan RTP tersebut. Di sisi lain, Teater Terbuka bukan merupakan RTP yang paling sering dikunjungi responden sebab utamanya ialah tidak aosiasi dengan gedunggedung utama aktifitas perkuliahan mahasiswa pendidikan geografi tahun angkatan 2016 biasa beraglomerasi yakni Gedung Dewi Sartika (GDS/IDB II), Gedung R.A Kartini (GRK/IDB I) dan Fakultas Ilmu Sosial (FIS).

Lynch, Kevin. 1960. The Image of the City. Massachusetts: The Technology Press \& Harvard University Press.

Purwanto, Edi. 2001. Pendekatan Pemahaman Citra Lingkungan Perkotaan (Melalui Kemampuan Peta Mental Pengamat). Dimensi Teknik Arsitektur Vol. 29, No. 1, Juli 2001: $85-92$.

Purwanto, Edi. Wijayanti. 2015. Gambaran Bentuk Spasial Kampus UNDIP Tembalang Menurut Kemampuan Peta Mental Mahasiswa. ISSN : 0853-2877 Modul Vol.15 No. 1 Januari-Juli 2015.

Sudrajat, Iwan. 1984. Struktur Pemahaman Lingkungan Perkotaan. Tesis S-2 Teknik Arsitektur: ITB 
Sugiyono. 2009. Metode Penelitian

Bisnis (Pendekatan Kuantitatif, Kualitatif, dan R\&D). Bandung: Alfabeta.

Sugiyono. 2012. Memahami Penelitian Kualitatif. Bandung: Alfabeta.

Tohjiwa, Agus. 2011. Citra Pusat Kota Depok Berdasarkan Peta Kognitif Pengamat. Depok: Universitas Gunadharma.

Wardhani, Aprilia. Artiningsih. 2009. Studi Pola Pemanfaatan Ruang Terbuka Publik Berdasarkan Lifestyle Mahasiswa Di Kampus Universitas GajahmadaYogyakarta. JURNAL TATA LOKA; VOLUME 11; NOMOR1; FEBRUARI 2009 : Biro Penerbit Planologi UNDIP. 